\section{Fighting for justice}

Despite an amendment to the Race Relations Act in 2000, which sought to make race relations a priority, the NHS still has a long way to go. Trevor Phillips, chairman of the Commission for Racial Equality, addresses the BMA

Last year the BMA took a battering on the issue of racial discrimination. The association was accused of institutional racism by one of its senior members; had to pay out almost $£ 1 \mathrm{~m}(\$ 1.9 \mathrm{~m}$; $€ 1.4 \mathrm{~m})$ in damages, costs, and interest to one Indian doctor; and was forced to settle another five race discrimination cases for an additional $£ 130000$ (BMJ 2004;329:161-3).

Since the events that led to the biggest case, the BMA has changed the way in which it offers advice to its members on racial discrimination and is working hard to increase awareness about race issues. To that end, Trevor Phillips, chairman of the Commission for Racial Equality, was invited to speak to the BMA council in December. After the meeting, the 51 year old former television presenter spoke to small groups of doctors about the problems the commission was facing.

Phillips said that complaints from doctors made up one of the largest categories of protests that the commission received. And certain grievances recurred with striking frequency-bullying, lack of access to appropriate training, barriers to promotion, exploitation, and, in particular, ethnic minority doctors being asked to do consultants' work while being paid on a lower grade.

Phillips, who came to the commission after a successful career at London Weekend Television and almost three years as chairman of the London Assembly, said that a great deal of his organisation's work with doctors went on behind the scenes, far from the public gaze. The commission gave legal support to individual doctors, with many cases being settled out of court, and consequently not attracting much publicity. "We are discussing with the BMA how we can support their attempts to identify reasons for these problems and how to solve the issues," he said.
"The high number of complaints we receive from SAS [staff and associate specialist] doctors is something that needs to be investigated. We need to know the actual reasons behind the current problems of the SAS doctor grade. If the problem is that they are not getting selected to become registrars then we need to find out why not and who makes the decision and on what grounds.

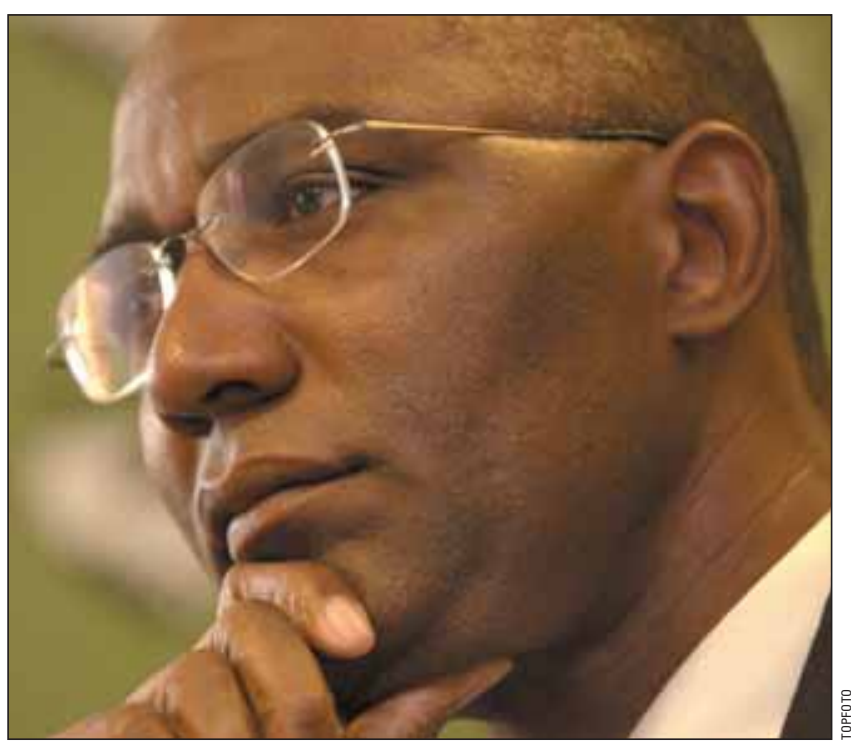

Trevor Phillips said complaints from doctors made up one of the largest categories of protests that the commission received

"Doctors from ethnic minority groups have tended to be offered more junior, or less secure positions, such as staff grade or locum posts, rather than becoming consultants or GPs.” If they got senior appointments, these were more likely to be in unpopular parts of the country, less prestigious institutions, or less popular specialties. There are only a handful of chief executives or managers of trusts from ethnic minorities, he said.

"We're looking forward to hearing from the BMA, who, as a trade union body, has the contacts, experience, and resources to investigate claims of discrimiadvertisements for the Halifax.

Born in London, but educated at secondary school in Georgetown, Guyana, Phillips first rose to prominence when he was elected president of the National Union of Students in 1978, while studying chemistry at Imperial College, London. He has consistently campaigned for greater equality in Britain, highlighting the plight of Britain's early immigrants when he initi- nation from their members and, in doing so, identify what discrimination may be taking place," he pointed out.

The relative scarcity of high profile Afro-Caribbeans in British public life is brought home regularly to Phillips by the fact that he is often mistaken either for the West Indian newscaster Trevor McDonald or for Howard from the television

12 month period, nearly $60 \%$ of respondents [in the NHS] had either witnessed or experienced racial harassment," he said.

An amendment to the 1976 Race Relations Act, which was passed in 2000, introduced a "race equality duty," which meant that all organisations in England, Scotland, and Wales had to make race relations an organisational priority. "With its introduction we advised many healthcare institutions how best to implement the changes designed to help all staff. We are now continuing this work with strategic health authorities to ensure that they monitor the implementation... of the race equality duty," he said.

He told the audience at the BMA that surveys of patients suggested that ethnic minorities on the receiving end of care also received unequal treatment, with South Asian patients in the most recent survey reporting the poorest experience of outpatient, emergency, and primary care. But he praised both the antenatal and newborn screening scheme for thalassaemia set up by Alan Milburn, former health secretary, and the NHS Improvement Plan as signs that the NHS was catering for diversity.

"All the evidence shows that black and minority ethnic people want the opportunity to choose. Their experience of bureaucracies making decisions for them, of telling them what is best for them, has not delivered them equity. They want the right to play a role and direct the way in which services are delivered. I think the plan will be complicated but good overall. It will be assessed for its impact and how it affects different kinds of staff and users."

He has great hopes of the NHS for the future. "The NHS should be an exemplar of the degree to which diversity can coexist with equality and fairness in Britain. It is clear that the NHS as an institution does more than distribute health care to the public, firstly as an employer, secondly as a service provider in the way in which it looks after its people, and lastly as part of the community it looks after. There is no part of Britain that does not have an NHS institution. The NHS could play a huge role in integration within communities," he concluded.

Samena Chaudhry London 